in Hancock County, across an open prairie of twenty-five miles; thence to Algona, crossing a wider stretch of open country, a total distance of sixty miles. The contractor for this work was Hewitt, an old Indian interpreter and thorough pioneer. He was sixty-three years of age, but strong as a man of forty; with ruddy face, bluff, hearty manners, and physically as "tough as a pine knot.". In preparation for his winter journeyings it was his custom to set up, in the fall, oak poles at intervals of about three-hundred yards, their leafy tops being retained; and these were his guides when the storm howled across his path. His mail cart was canvas-covered on all sides, with small port holes for the reins to pass through, sockets for candles on the wooden supports, and plenty of fatty provisions. Thus armed, if his team gave out after nightfall, it was sheltered on the lee side of the canvas; he lit his candles for warmth, ate his provisions, and wrapped in buffalo robes stood out the siege until morning. With such thorough preparations death need not have happened to any settler; but the proverbial heedlessness of frontier people seldom impelled them to make them. They trusted to luck and to their " jedgment" of the weather, much as sailors are reputed to do, and often with like results. But these were the men who pioneered the way for our'modern farms, with artificial groves, furnace-heated houses, and defiance of the worst storms. Their memory and their fate are worthy of a better pen than mine.

\title{
AN INDIAN TREATY AND ITS NEGOTIATION.
}

BY HON. ALFRED HEBARD.

In compliance with a partial promise, I now venture to make a few statements, entirely from memory, relative to a treaty made with the Sac and Fox Indians some fifty years ago-a treaty hardly second in importance to any one ever made with the Red Man-especially if judged from the stand-point of the present day; because the large amount of land then acquired, 
though as yet far from being fully improved, has developed $\mathbf{a}$ food-producing, life-sustaining capacity unsurpassed by any tract of like extent on the face of the earth. Great credit is due the United States Commissioner who carried through so happily and so successfully the difficult and complicated negotiation. That Commissioner was Major John Chambers, of Kentucky, who at the time held the position of Governor of the Territory of Iowa, being the second Territorial Governor before Iowa left her minority and assumed her position as an independent State of the Great Union. And right here I deem it fitting that I say something more of John Chambers than the mere mention of his name. Men in important posjtions, who are distinguished for conscientious and successful discharge of official duty, affecting the welfare of their fellowmen, are entitled to grateful recognition. With Major Chambers duty was first, consequences took care of themselves. In appearance he was of medium height and slightly robust. In bearing, dress and address, a gentleman-without the slightest suggestion of personal consequence on his own part; genial, affable and sympathetic, with all who were entitled to regard. Very soon after his arrival among us he identified himself with the leading interest of the country, by purchasing a tract of land some six miles west of Burlington, on which he built a comfortable home and made improvements that were exemplary to the neighboring farmers. His two younger sons he placed in a family where they could pursue their studies a part of the time, and a part of the time engage in and become familiar with industrial pursuits - believing that useful occupation was no small part of a valuable education. It would be well if others of the present day entertained similar views. One of these sons died in his youth, the other grew up, acquired wealth, character and reputation, possibly the result of parental example and sensible education.

Iowa was at first known to the outside world as the "Black Hawk Purchase." It lay on the west side of the Mississippi River and extended west a little beyond Fairfield, Jefferson County, embracing but a small part of the present area of the 
State. Whether the Indians zeillingly surrendered the lands embraced in this purchase, or were governed by a necessity following their defeat, is immaterial. The coveted lands were secured and in due time thrown open to settlement, and many a wanderer in search of a home was diverted to the "Black Hawk Purchase" by the universal report of the beauty and value of the country. Among those wanderers in search of a home was the writer hereof, as early as i 837 . Black Hawk having been deposed after his defeat, Keokuk, who was peaceably inclined, became Chief of the nation. Aside from the territory already ceded the Indians held and occupied a very large body of land in the middle and southern part of the present State, amounting to some twelve or fifteen millions of acres. As our population increased, it became more and more desirable that these beautiful lands should be rescued from the occupancy of bands of roving savages, and opened to settlement by an industrious and intelligent civilization. Responding to this general feeling, the Government at Washington appointed Governor Chambers a Commissioner on behalf of the United States to hold a council with the Indians, and secure if possible the desired results. No better appointment could have been made, because Governor Chambers was not only a good lawyer, but a man of prudence, patience, and rather remarkably good business judgment. Aside from the fact that previous experience had given him a knowledge of Indian character, he had lived here in Iowa, as a neighbor of these Indians, long enough to be somewhat familiar with their character and to understand the complicated relations that had grown up between them and their white neighbors. His home was only seventy miles from their great trading-houses on the Des Moines, the real center of Indian life. The United States agency was nearer still-at Agency City, some six miles east of Ottumwa. These relations grew mostly out of trade in some shape, but illicit whisky, horse-racing and other various kinds of gambling were no inconsiderable factors. Aside from the accounts of the licensed traders, scores of other smaller claims had been carefully nursed with the expec- 
tation that they would be allowed, en masse, whenever a sale of their lands was made to the Government. The rigid examination required by the Commissioner was unexpected, but the rule was inflexible-evidence and reasonable explanation were required in all cases.

Notwithstanding their obligations the Indians were at first reluctant to give up the whole of their country, of which they were justly proud. In formerldays game had been abundant, wild fruits were scattered through the groves, and even the hollow trunks of trees along the principal streams were filled with the delicious product of the busy-working bees. Although insufficient for their present support, there was a latent, lingering attachment hard for them to sever. The Commissioner, fully appreciating the condition of things, avoiding any hasty or abrupt movement, sought patiently to create' a common sentiment favorable to the object of his mission, by making use of the various means of influence within his reach.

At the appointed time the tribes had been gathered and camped near the site of the present town of Agency City. Captain Allen, with his command of United States dragoons stationed at Fort Des Moines, had been ordered to be in attendance to guard against disturbances-and more needed to watch over troublesome whites than over Indians. For a council chamber the Agent, Captain Beach, had prepared a large circular tent, with a slightly raised platform on one side for the Commissioner, his interpreter, and a few others. The interpreter was the well known Antoine Le Claire, of Davenport. A circular row of seats ran around the body of the tent for the accommodation of the chiefs. There was not as much ceremony as I suppose there was at the coronation of Queen Victoria, but much more than I had expected.

By the advice of General William Henry Harrison ("old Tippecanoe"), whose early life had been spent among the Indians as Governor of the Northwest Territory, our Commissioner donned the full uniform of a Brigadier General of the United States Army. After taking his seat with his interpreter and his unadorned aids, Keokuk and his fellow chiefs filed 
in slowly and as gravely as a band of Roman SenatorsKeokuk directly in front of our now General Chambers, with ihis braves on either side. All being seated, our showy Gen. eral arose and addressed his "friends and brethren" in a very complimentary speech, which was "Indianized" by our interpreter as he went along, sentence by sentence. This speech was full of fine adjectives and friendly sentiments, but meaning little more than a cordial, ceremonious introduction. In response, Keokuk quickly rose, took a few measured steps to the middle of the open area, raised his right hand, glanced at his comrades, and said: "We are happy to meet you here to-day, as the representative of our Great Father in Washington, in friendly council." His address was also Anglicized by the interpreter as he spoke, but was apropos and fitted to the occasion. A glance at his bearing-his self-possession-his intellectual and expressive countenance-at once revealed his great superiority over his fellows. All was in keeping with the fashion of the present day-considerable fine talking, but little of importance said. After these opening speeches and general greetings at the first council, there was a general hand-shaking and all retired. The Indians in their appearance were not outdone by our showy Brigadier. Each wore his best blanket, freshly painted with gay fantastic figures, with feathers and fine plumage in the hair. Many wore bracelets on their wrists and various." dangles" in their ears, having a fancy war-club in one hand, richly embossed with largeheaded brass nails. I think a good photographic view of the personnel of the entire council in session, Brigadier and all, would rival any made last summer in the White City.

In the daily meetings of the council the fact was still further revealed that there was one master mind among the Indians, with whom we should have to deal-and that was Keokuk, not only head chief but head and shoulders above all his associate chiefs. His individuality was marked-his oratory was proverbial-so intense and energetic were his words and his gestures, when aroused, that he would carry his audience with him whether they understood a word or not. He was 
the Daniel Webster of the tribe. Our organization being: completed and ceremonious introductions over, the first thing by way of business was to ascertain the amount of obligations. the Indians were honestly under to their white neighbors, as well as to the large licensed traders. To this end all parties. interested were allowed to present their claims with such explanatory statements and evidence as they were disposed to offer. After careful examination, each claim was presented to the Indians in council, to hear what they had to say, and no claim was to be allowed until after such presentation. The duty of examining and sifting these claims was assigned to the late General A. Bridgman, of the city of Keokuk, and myself-and a heavy job it was. In amount they ran up to about a quarter of a million dollars, and kept us very busy for over three weeks, all the days and half the nights-for which service we received our camp, fare free, and the liberal sum of: three dollars a day in cash for the time actually employed. Financially, it did not make us, and I trust it did not break "Uncle Sam" or anybody else. There were three large firms licensed to trade with the Indians. The principal or largest one was that of a Fur Company in St. Louis, headed by a Mr. Choteau and conducted by his son-in-law, Major Sandford. Another was that of the Ewing Bros., of Indiana. Both of these were located on the Des Moines river where the city of: Ottumwa now stands. The third establishment was managed by a former merchant of Burlington by the name of Eddy, from whom the Eddyville of to-day took its name. The accounts. of these traders constituted the bulk of the indebtedness. Bills were sometimes made by large parties outfitting for theirfall hunts, as high as ten thousand dollars at a time. Prices were liberal at least, if not high, and in most cases allowed on account of the risk and uncertainty in the trade. So far as clothing was concerned, the Indians would have only the very best. No mean blankets, or cheap, thin broadcloth, or poor quality of calico, could be sold to them at all. They were judges and would not be imposed upon. We found upon examination. 
that goods of this kind were of a high grade in all the trading: houses.

To the credit of the Indians there appeared to be no disposition to avoid the payment of their just debts-the accounts of large traders they said were too long for their memories; we must look them over and whatever we thought was right they would agree to. Hence it became necessary to examine in. detail all these large bills-comparing prices charged with purchase prices as shown by their invoices, for the Commissionerwas determined that nothing that could be ascertained, should be left to any blind guess work. These accounts were less troublesome because regular books had been kept; not so with the many smaller outside claimants. Their accounts were often sharply criticised and in many cases materially modified. One. instance will explain others. A party living near Iowaville brought in a bill for beef supplied. There was a hurried and exciting talk which we did not of course understand; but Keokuk jumped up and with a loud voice said, "Throw that out! that worthless old bull has been too much paid for already!" and that was the end of the claim.

Several others were served in a similar way, or greatly reduced. When we found satinet coats charged at sixty dollarseach by small outside traders, we considered it liberal to divide the claim by the figure two at least. Claims, however, that had: a prima facie appearance of fairness, and were sustained by explanation, seldom met with opposition or a word of complaint - showing an element of honesty in the Indian character not always found among many of those with whom they had been. dealing. But the acts of an unscrupulous few who drift along the borders between savage and civilized life, should characterize nobody but themselves.

While the early ceremonious councils were being held, and the accounts or claims were being received, sifted and arranged, there was a busy activity in securing influences to help toward effecting our object. Persons known to, and knowing the Indians, and having their confidence, especially those who could speak their language, were invited and requested to. 
aid our negotiations. Among those giving their aid was Major Stanford of the Fur Company, extensively and favorably known and recognized as a friend. Those having claims had a double motive, and citizens generally were interested in the same direction, thus creating a pressure of public opinion, that greatly assisted the Commissioner in his patient, persuasive reasonings with the Indians, in trying to convince them that their true interest would be promoted, by accepting a smaller home farther west, with increased means of support and free from border entanglements. Although finally successful, there was no motive, reason or argument, to spare. The Indian heart appreciates friendship, and had it not been for this strong undertone of faith in known friends, I doubt it the mission had been fully successful. The aid of Major S. and others is entitled to just appreciation to this day. The entire Indian title was extinguished, the lands opened to settlement, and all future embarrassment avoided.

When the real question-the terms of sale-was taken up, the claims and debts having been pretty thoroughly considered there was little of incident worth recording-except the speechmaking, and the great effort to brag up the country-an effort in fact to drive a good bargain as well as to make a display. Keokuk was too shrewd and too wise a man not to have seen the end from the beginning. He said little at first, but allowed bucks and braves to talk all they pleased-in fact allowed them to think they were "doing it all." Their general oratory, in which many seemed to take pleasure, followed a common line of thought, giving it a tone of sameness and monotony; and still, it was not without interest. They claimed that the "Great Spirit" made this beautiful country, and made the Indian and put him in it. His title then ran back to the beginning of things. There was no question about that. No memory of man recalled-no tradition lever taught anything to the contrary. Tribal relations sometimes changed and occupied different localities, but the race held possession. The features and good qualities of the country were a prolific theme, and no one familiar with the virgin lands of Iowa, before they were marred 
and disfigured by the plow and the harrow, would gainsay a word of their proud description. In journeying over them one felt a quickened motion in his pulses, there was so very much air to breathe, such endless range, unhindered by a single line of severalty or demarcation. Evidently the Indians. were lovers of nature and appreciated her beauties. They talked of their great meadows of green, gay in the aftermonths. of the season with blooming flowers-of the springs and running streams-of the groves that bordered the streams, and especially of the great sycamores and walnuts, that stood in. vast numbers on all the larger alluvions. Sad to say, they have nearly all been destroyed in later days, by the axe and the saw of our boasted civilization. They talked of the sun and the moon, as though made for them-of the stars, with a kind of wondering delight, as guardian watchmen-of their Great Spirit hovering over them, perhaps, but they did not know. Wherein do they differ from us? who does know? Science, taking a hint from nature, has wrought out wonderful problems. But whoever attempts the "Stary Realm" will soon find a limit to his pen. Savant or savage, "if we would declare them and speak of them, they are more than we are able to express." We know not their whence or their whither, their when or their where. All of us are lost alike in a mystery of mysteries yet unrevealed.

After this efflorescence of oratory by the Chiefs and braves were over, and the real business was brought forward, Keokuk resumed his place as Head Chief of the trites. The terms and details were soon arranged. A public sentiment had been worked up in favor of the proposition of the Government, as presented by the Conmissioner, so that the whole subject became a matter of easy solution. A small tract of land, or Reservation, was to be assigned them in Kansas as their future home, and a money balance of twelve hundred and fifty thousand dollars allowed them, for relinquishing their entire body of lands in Iowa. From this sum was to be deducted the amount of their debts ascertained as before described, leaving about a million dollars or more to be invested in the usual way,. 
from which they were to derive a stated income. This, added to previous resources, made them very independent, becoming more so, individually as their numbers diminish. The cost to the Government of the land released did not very far from "(I2) cents an acre. "What robbery," says some sentimental sympathizer. It was no robbery at all. The bargain was a good one for all concerned-especially for the Indians. Though -still intense in their native prejudices, they had borrowed habits from their white neighbors, giving rise to wants, which the chase and their indolent habits could not supply. They were human and needed food and raiment of some kind. The " Great Spirit" had made them swift of foot, and they were : skillful marksmen with the bow and arrow, but the buffalo had disappeared, and smaller game was becoming less. They needed blankets for their braves, and clothes and chintres for the use of their squaws and pappooses.

The skins of animals were becoming scarce, and they did not find these needed articles hanging on the limbs of their great trees of which they were so proud. They wanted arms, ammunition, traps, hatchets. Their "Great Spirit," whom they referred to so often, had failed to supply a magazine of these things from which they could draw at will. It required means to supply these wants, and the sale of their lands furnished them. Thus they became independent, and if reports are correct they are so to this day. At the close, the Commissioner gave them some kindly advice-not only to live peaceably, but - especially to engage in the industrial pursuits. Occupation would keep them from evil, and greatly increase their comforts of life. The advice was respectfully listened to but little heeded. The idea that a proud buck, in his gaily painted blanket and feathers, should make a squaw of himself by delving the earth with a hoe, was abhorent to his hereditary instincts. Since the the time of the treaty I have been considering, great efforts have been made to improve the Indian and give him character, and it would be untrue to say there has been no success; but far less than had been fondly hoped; certainly. With the ex-ception of a few tribes at the South-Chickasaws, Choctaws, 
Seminoles, etc., the great mass to-day are Indians still. Even among the students, who have been educated and apparently reformed, many on returning to, their own, having been overcome by their strong tribal instincts and lost what they were supposed to have gained.

Whether the Indians generally can be tamed, improved and transformed into a useful and self-respecting manhood, before the present generation shall have passed away and successors come upon the stage, less under the influence of hereditary bias, is a problem that must wait on the future for its solution. Tribes differ somewhat, but the great multitude are devoid of any traits of character that would hold them up above the. lowest plane of life.

Without individuality, except in a few instances like Keokuk, Sitting Bull and some Choctaw Chiefs, they drag along an indolent life, without any just pride, or aspiration for anything higher or better. Imbibing many of the vices, and. few of the virtues of the neighboring whites, they deteriorate till they become spoiled Indians rather than civilized men: The policy of our Government has been, and is, liberal toward them. We take no land from them by. conquest, but. acquire it by mutual agreement, rendering to them considerations more than are equivalent for what they surrender. ... Their lands are made useful only by skillful industry. To this the Indian is averse: when the question with him is doing or dying, he prefers the latter unless, it be in the chase or some of his tribal amusements. If the Creator (their "Great Spirit") had a purpose in giving such a wonderful fertility to these great plains, the blessings therefrom were available on conditions: The hand must be stretched forth in active industry, and not folded idly on the bosom. The white man will comply, the Indian will not. Who could or would avert the consequences? There is an imperative decree, ordained of fate, that the " fittest shall survive." Intelligent industry must prevail over indolent ignorance, and the Indian races generally, sooner or later, will; like the "Lost Arts", probably be among the things that have been. If what I have written, should throw a ray of light on 
an important initial step in the formation of this great com-monwealth of Iowa, the intent will not have been in vain.

If some one in Lee County, who was "on deck" fifty years. ago, and whose memory has not forsaken him, will write the story of "The Half Breed and the 'Possum," another reminiscence will be placed upon the record, possibly to be of use to the future historian.

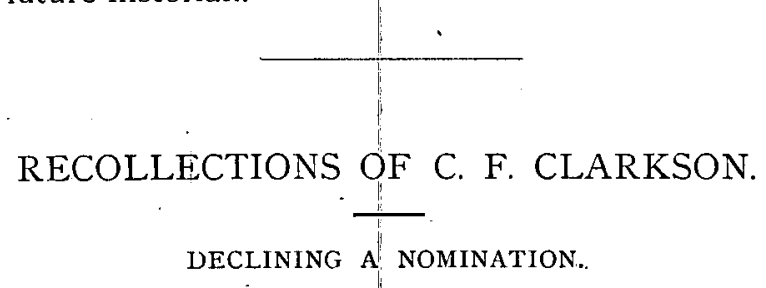

In the summer of I 856 a Republican Convention was held at Eldora to nominate a candidate for delegates to the State Constitutional Convention from the Senatorial District, composed of the following counties: Fayette, Bremer, Butler, Franklin, Grundy, Hardin, Hamilton, Wright, Webster, Boone, Story, Greene and Humboldt. Of course there was no way to reach Eldora except by private conveyance. The consequence was that none of them were fully represented, except Hardin. The writer was the delegate from Webster, and had proxies for Humboldt and Greene. He left Fort Dodge for Eldora the morning of the day preceding the convention, and arrived at Webster City at noon. Here he was joined by Morgan .Everts, the delegate from Hamilton county, who also had a proxy for Wright. Occupying the same conveyance, we drove across the then sparsely settled prairie, arriving at Eldora late in the evening. The next morning when the delegates from the different counties had arrived we found that there was really no declared candidate for the nomination, except that the delegation from Hardin county proposed to present the name of S. G. Winchester, of Eldora. Everts and the writer talked the matter over, and concluded it would at least enliven the proceedings a little by having a. candidate of our own. Among the delegates was a man by the name of Seeley, and who was the sole representative from. 
Copyright of Annals of Iowa is the property of State of Iowa, by \& through the State Historical Society of Iowa and its content may not be copied or emailed to multiple sites or posted to a listserv without the copyright holder's express written permission. However, users may print, download, or email articles for individual use. 